\title{
A IMPORTÂNCIA DA AFIRMAÇÃO DE DIREITOS PARA O EMPODERAMENTO DA MULHER NEGRA ${ }^{1}$
}

THE IMPORTANCE OF ASSERTING RIGHTS FOR THE EMPOWERMENT OF BLACK WOMEN

\author{
Aline Andrighetto ${ }^{2}$ \\ Siméia da Silva Barbosa ${ }^{3}$
}

Resumo: O presente estudo tem como objetivo analisar a contribuição dos movimentos das mulheres negras no âmbito jurídico, bem como a vedação ao direito fundamental à igualdade de tratamento garantido constitucionalmente no mercado de trabalho. Em suma, a pesquisa pretende abordar os desafios enfrentados por mulheres negras, ao longo do tempo, em busca de igualdade de direitos civis, sociais, políticos e culturais estabelecidos no ordenamento jurídico e a busca pelo trabalho formal. Para isso, além de uma pesquisa de caráter bibliográfico, foi aplicado um questionário qualitativo às mulheres integrantes da Comissão Especial da Igualdade Racial da OAB/RS. A escolha pelo grupo se deve à sua representatividade nesse espaço institucional e à sua forte atuação social. Pretende-se assim esclarecer a importância dos movimentos sociais para o combate da discriminação e da desigualdade de gênero e raça no mercado de trabalho.

Palavras-chave: Mulheres Negras; Igualdade; Discriminação no Trabalho; Desigualdade.

\begin{abstract}
This study has as its main goal to analyze the contribution of black women's movements in the juridical scope, as well as the fence to the fundamental right to equal treatment constitutionally guaranteed in the labor market. In short, the research intends to approach the challenges faced by black women, over time, in quest of equality of civil rights, socials, politics and cultural, stablished in the legal system and the search for formal work. Besides the character bibliographic of the research, it was applied a qualitative survey to the black women who integrate the Special Committee of Racial and Equality of OAB/RS. The choice of the group was due to the representativeness that the institutional group and to the performance strength. The intent is to clarify the social of the movement to avoid genre and race discrimination in the job market.
\end{abstract}

Keywords: Black Women; Equality; Discrimination at work; Inequality.

\section{Introdução}

\footnotetext{
${ }_{1}^{1}$ Artigo submetido em 22/07/2019 e aprovado para publicação em 14/06/2020.

${ }^{2}$ Doutoranda em Direito Público pela Unisinos. Professora do curso de Direito no Centro Universitário Cenecista de Osório- UNICNEC. ORCID: https://orcid.org/0000-0002-0548-8979.

3 Bacharel em Direito pelo Centro Universitário Cenecista de Osório- UNICNEC. ORCID: https://orcid.org/0000-0003-1950-7074
} 
$\mathrm{Na}$ atual sociedade brasileira, a população negra continua enfrentando desigualdades e discriminação no âmbito social, diante da presença do racismo institucional no país. Tais condutas de preconceito são o grande desafio em relação ao processo de inclusão no ambiente de trabalho, considerado o grupo mais afetado na escala de desigualdade social.

Ao referir-se à mulher negra, a situação é ainda mais complicada, tendo em vista carregar duplicidade de discriminação, gênero e raça, bem como estar em desvantagem social em vista de sua identidade negra. Nesse sentido, importa questionar se o direito fundamental à igualdade está sendo respeitado no que diz respeito às mulheres negras em ambientes institucionais. Para responder esse questionamento, utilizou-se, além da pesquisa bibliográfica, uma pesquisa qualitativa, realizada com mulheres da Comissão Especial da Igualdade Racial da $\mathrm{OAB} / \mathrm{RS}$, referente às dificuldades e diferenças suportadas por mulheres negras no ambiente de trabalho. O questionário, elaborado pelas autoras, com perguntas de respostas abertas, buscou compreender quais os momentos mais constrangedores para as mulheres negras em determinados ambientes, públicos e privados. Como foco principal procurou identificar atos discriminatórios no ambiente de trabalho e ainda descobrir se o público alvo reconhece avanços em políticas para o combate à discriminação de gênero e raça. Ademais, buscou-se verificar a necessidade de implementação de políticas públicas como medidas estatais para combater a discriminação e desigualdade de gênero e raça na sociedade, a fim de que essas práticas sejam ampliadas ao ambiente corporativo também na iniciativa privada, mediante contribuição do Poder Público.

O objetivo principal da presente pesquisa, portanto, é verificar a aplicabilidade do ordenamento jurídico brasileiro com relação à diminuição da discriminação e desigualdade sofrida por mulheres negras no ambiente de trabalho. Dessa forma, verifica-se a aplicação dos princípios da igualdade e da não discriminação previstos na legislação brasileira.

A escolha desse tema justifica-se por ser atual e de suma importância, uma vez que abrange tanto a questão de raça quanto a de gênero, merecendo assim um estudo científico específico devido às discussões em relação à equiparação de mulheres negras em ambiente de trabalho, com vistas a diminuir a discriminação e desigualdade de gênero.

Dessa forma, refletir criticamente sobre o assunto torna-se fundamental para analisar direitos propostos às mulheres negras que têm a finalidade de promover o chamado empoderamento. Este demonstra a necessidade de autoafirmação de grupos minoritários, que atualmente abrangem pessoas que sobrevivem às adversidades diárias do sistema de opressão. 
Com base nesse contexto, o presente estudo apresenta o conceito de direito à igualdade e a luta da mulher negra pela não discriminação de gênero e raça no ambiente de trabalho, verificando assim as contribuições dos movimentos sociais das mulheres negras no Brasil. Em um segundo momento, será realizada uma análise na perspectiva de gênero, raça e classe no ordenamento jurídico, bem como o estudo da Identidade da mulher negra. Por fim, aborda a violação de direitos humanos e a importância da afirmação de direitos para o empoderamento da mulher negra.

\section{Direito à igualdade e a luta da mulher negra pela não discriminação}

É de suma importância esclarecer que o direito à igualdade e não discriminação faz parte dos princípios que norteiam os direitos fundamentais e os direitos humanos, contudo esses dois conceitos são compreendidos conjuntamente, conforme será exposto com maior profundidade no presente capítulo.

A Constituição Federal $^{4}$ de 1988 (CF/1988) é a lei fundamental do Brasil, pois estabelece normas que são dominadas pelo ordenamento jurídico brasileiro, sendo considerada a constituição cidadã. A Carta Magna desenvolveu proventos aos cidadãos brasileiros, proporcionando ampliação das liberdades civis, uma vez que elaborou direitos e garantias fundamentais com relação aos direitos coletivos e individuais. É importante observar que os direitos previstos na Constituição Federal se relacionam com as dimensões de desigualdade de gênero suportada por mulheres negras na atual sociedade brasileira. Dessa forma, determina o artigo $5^{\circ}, 1$, da $\mathrm{CF} / 1988^{5}$ :

Art. 5. Todos são iguais perante a lei, sem distinção de qualquer natureza, garantindo-se aos brasileiros e aos estrangeiros residentes no País a inviolabilidade do direito à vida, à liberdade, à igualdade, à segurança e à propriedade, nos termos seguintes:

I - Homens e mulheres são iguais em direitos e obrigações, nos termos desta Constituição; [...].

A previsão do artigo citado presume igualdade a todos, sem distinção de qualquer pessoa, estabelecendo direitos aos indivíduos e garantias fundamentais. Segundo o dispositivo mencionado, a legislação atual do país tem como importante concepção o princípio da

\footnotetext{
${ }^{4}$ BRASIL. [Constituição (1988)]. Constituição da República Federativa do Brasil. Brasília, DF, 1988. Disponível em: http://www.planalto.gov.br/ccivil_03/constituicao/constituicaocompilado.htm. Acesso em: 4 maio 2019.

${ }^{5}$ Ibid.
} 
igualdade que assegura essa prerrogativa a todos os cidadãos, portanto, em qualquer situação, não poderá ocorrer desigualdade.

Em equivalência com o princípio da igualdade, a CF/1988 considera como um direito fundamental a proibição da discriminação, sendo considerada um dos objetivos fundamentais. Nesse sentido está previsto no artigo $3^{\circ}$, inciso IV: "Constituem objetivos fundamentais da República Federativa do Brasil: [...] IV- promover o bem de todos, sem preconceitos de origem, raça, sexo, cor, idade e quaisquer outras formas de discriminação”.

Portanto, o presente dispositivo indica os objetivos fundamentais da República Federativa do Brasil, estabelecendo a proibição de qualquer forma de discriminação ou preconceitos. Com relação à importância dos objetivos fundamentais elencados na Constituição, Silva $^{6}$ dispõe que:

É a primeira vez que uma Constituição assinala, especificamente, objetivos do
Estado brasileiro, não todos, que seria despropositado, mas os fundamentais, e, entre
eles, uns que valem como base das prestações positivas que venham a concretizar a
democracia econômica, social e cultural, a fim de efetivar na prática a dignidade da
pessoa humana.

Os direitos fundamentais têm como elemento básico a realização de um Estado Democrático de Direito. Por sua vez, é fundamental construir uma sociedade livre, justa, solidária, reduzir as desigualdades e promover o bem de todos, sem preconceito de raça, sexo, cor e idade. ${ }^{7}$ Como afirma José Miranda ${ }^{8}$ :

A Constituição confere uma unidade de sentido, de valor e de concordância prática ao sistema de direitos fundamentais. E ela repousa na dignidade da pessoa humana, ou seja, na concepção que faz a pessoa fundamento e fim da sociedade e do Estado.

Nesse sentido, a igualdade e a discriminação dominam sob o binômio de inclusãoexclusão. Ao passo que a igualdade presume formas de inclusão social, e a discriminação requer exclusão e intolerância às diferenças. Dessa forma, Flavia Piovesan" explica que "Não é suficiente proibir a exclusão quando o que se pretende é garantir a igualdade de fato, com a efetiva inclusão social de grupos que sofreram e sofrem um persistente padrão de violência e discriminação".

\footnotetext{
6 SILVA, José Afonso. Curso de direito constitucional positivo. 37. ed., ver. e atual. até a Emenda Constitucional n. 76, de 28.11.2013. São Paulo: Malheiros Editores, 2014. p. 107.

${ }^{7}$ PIOVESAN, Flávia. Direitos humanos e o direito constitucional internacional. 11. ed., ver. e atual. São Paulo: Saraiva, 2010. p. 26-27.

${ }^{8}$ Apud Ibid., p. 26.

${ }^{9}$ PIOVESAN, Flávia. Temas de direitos humanos. 4. ed. São Paulo: Saraiva, Leila Linhares, 2010. p. 245.
} 
Assim, como importante instrumento de inclusão social estão as ações afirmativas, que constituem medidas específicas, buscando amenizar o passado discriminatório e agilizar os procedimentos de igualdade. Dessa forma, tenta-se alcançar a igualdade, apesar do sofrimento de grupos vulneráveis, como os de minorias étnicas e raciais, mulheres, dentre outros grupos. $^{10}$

Os instrumentos jurídicos de aplicação do direito à igualdade e não discriminação constituem medidas que têm por objetivo a inclusão social e inserção das minorias, além de contribuições para diminuir a discriminação, o preconceito e as desigualdades sociais, porém não se efetivam diante da realidade e da herança do patriarcado ainda presentes na sociedade brasileira.

\subsection{Discriminação de gênero e raça no ambiente de trabalho}

$\mathrm{Na}$ atual sociedade brasileira, mulheres continuam sendo vítimas de preconceitos em consequência da falta de tratamento igualitário. Apesar de terem conquistado espaços no âmbito institucional, ainda sofrem com as piores colocações no ambiente de trabalho. ${ }^{11}$

Existem normas internacionais que visam à proteção e proibição de discriminação de gênero no emprego, como a Convenção n. 111 da Organização Internacional do Trabalho (OIT), que foi elaborada em 1958 e ratificada pelo Brasil em 1965. Essa Convenção estabelece medidas contra a discriminação ${ }^{12}$, uma vez que

discriminar significa fazer distinção, exclusão ou preferência, com base em raça, cor, sexo, religião, opinião política, nacionalidade ou origem social, que tenha por efeito anular ou reduzir a igualdade de oportunidades ou tratamento no emprego ou profissão.

A $\mathrm{CF} / 1988^{13}$ estabelece em seu artigo $7^{\circ}$, inciso XX, a proteção do mercado de trabalho da mulher, prevendo a proibição do tratamento diferenciado no que diz respeito a

\footnotetext{
${ }^{10}$ Ibid.

${ }^{11}$ GROSSI, Miriam Pillar; SCHENDEILWEIN, Izabela Liz; MASSA, Jimena Maria. Discriminação tem gênero no brasil. GV-executivo, v. 12, n. 1, jan.-jun. 2013. Disponível em: https://rae.fgv.br/gv-executivo/vol12-num12013/discriminacao-tem-genero-no-brasil. Acesso em: 14 maio 2019.

${ }^{12}$ PORPINO, Henrique Braga. Discriminação de gênero nas relações de trabalho: entre o reconhecimento e a efetividade na equiparação de direitos. Âmbito Jurídico, Rio Grande, v. XXI, n. 171, abr. 2018. Disponível em: http://www.ambito-juridico.com.br/site/?n_link=revista_artigos_leitura\& artigo_id=20365\&revista_caderno=25. Acesso em: 7 maio 2019.

13 BRASIL. [Constituição (1988)]. Constituição da República Federativa do Brasil. Brasília, DF, 1988. Disponível em: http://www.planalto.gov.br/ccivil_03/constituicao/constituicaocompilado.htm. Acesso em: 4 maio 2019.
} 
gênero, consagrando o princípio da igualdade em relação à discriminação ao trabalho feminino:

Art. $7^{\circ}$ São direitos dos trabalhadores urbanos e rurais, além de outros que visem à melhoria de sua condição social: [...]

XX - proteção do mercado de trabalho da mulher, mediante incentivos específicos, nos termos da lei; [...].

Nesse sentido, o referido artigo apresenta uma importante norma jurídica a qual possui o intuito de proteger o trabalho da mulher, garantindo o exercício dos direitos fundamentais estabelecidos na Constituição Federal.

Outro instrumento importante foi a criação do Estatuto da Igualdade Racial, o qual contribuiu para o fortalecimento das perspectivas de gênero e raça, buscando melhorias nas condições de trabalho e diminuindo a exclusão social, garantindo respeito aos direitos fundamentais dos trabalhadores e para a igualdade de gênero e raça com a finalidade de adentrar no mercado de trabalho em pé de igualdade. ${ }^{14}$ Observa-se o disposto no artigo $39, \S$ $4^{\mathrm{o}}$, do presente Estatuto ${ }^{15}$ :

\footnotetext{
Art. 39. O poder público promoverá ações que assegurem a igualdade de oportunidades no mercado de trabalho para a população negra, inclusive mediante a implementação de medidas visando à promoção da igualdade nas contratações do setor público e o incentivo à adoção de medidas similares nas empresas e organizações privadas. [...]

$\S 4^{\circ}$ As ações de que trata o caput deste artigo assegurarão o princípio da proporcionalidade de gênero entre os beneficiários.
}

Todavia, verifica-se que embora algumas mulheres consigam conquistar direitos e oportunidades, ainda existem insuficiências para promover a redução nas discriminações raciais e de gênero, tornando-se assim um desafio importante combater a discriminação da mulher no Brasil, visto que se tornou o grupo mais vulnerabilizado da sociedade brasileira.

\footnotetext{
${ }^{14}$ SIMÃO, Calil (coord.). Estatuto da igualdade racial: comentários doutrinários. Leme, SP: J. H. Mizuno, 2011. p. 225-226.

${ }^{15}$ BRASIL. Lei n. 12.288, de 20 de julho de 2010. Institui o Estatuto da Igualdade Racial; altera as Leis nos 7.716, de 5 de janeiro de 1989, 9.029, de 13 de abril de 1995, 7.347, de 24 de julho de 1985, e 10.778, de 24 de novembro de 2003. Disponível em: http://www.planalto.gov.br/ccivil_03/_Ato2007-2010/2010/Lei/L12288.htm. Acesso em: 23 set. 2018.
} 
As condutas racial e de gênero ${ }^{16}$ impossibilitam a inclusão de mulheres, especialmente negras, ao mercado de trabalho, como verifica-se no momento da promoção ao cargo de chefia, com a menor presença no trabalho e no fato de receberem salários menores. Portanto, as mulheres negras sofrem duplamente com o excesso de preconceito. ${ }^{17}$

Pesquisas $^{18}$ referem que a mulher negra atualmente ocupa cargos inferiores, sendo explicitamente desvantajosa sua participação no mercado de trabalho, e quando consegue ocupar um cargo superior ainda enfrenta o preconceito racial, como demonstra o trecho de Bento $^{19}$ :

Há décadas a mulher negra vem sendo apontada como aquela que experimenta a maior precariedade no mercado de trabalho brasileiro. Entretanto os estudos que aprofundaram a perspectiva de gênero raramente levam em consideração a variável cor.

Diante de legislações no ordenamento jurídico, as condições de trabalho impostas às mulheres negras não garantem uma posição profissional digna, que possa garantir a qualidade de vida e dar apoio para seu crescimento profissional. Segundo $\operatorname{Santos}^{20}$ :

\begin{abstract}
Apesar dos avanços alcançados pelas mulheres no mercado de trabalho, ocupando posições importantes a nível profissional, este avanço é muito reduzido quando se observa o universo negro. Há poucas mulheres negras trabalhando como executivas, médicas, enfermeiras, juízas, dentre outras profissões de destaque; o que se verifica ainda é a grande maioria realizando trabalhos domésticos e recebendo baixos salários.
\end{abstract}

A partir da constatação de diferença de renda entre homens e mulheres, que fica entre $25 \%$, percebe-se que a profissionalização não garante acesso ao trabalho, com isso a conjugação entre gênero, raça e classe se constitui de fato. Ademais, mulheres brancas, com

\footnotetext{
16 "Isso demonstra que a sociedade tem um marcador racial bastante presente, que retira da população negra a possibilidade de concorrer em condições de igualdade com as demais pessoas e, a partir daí, faz com que a população negra viva situações de exclusão, que devem ser eliminadas para que a gente possa realmente dizer que vive em um país onde todos são iguais" (SUPTITZ, Bruna. Para Karen Pinheiro. Entrevistada: Karen Luise Vilanova Batista de Souza Pinheiro. Jornal do Comércio, 19 nov. 2018. http://www.ajuris.org.br/sitenovo/wpcontent/uploads/2018/11/19-11-2018-Entrevista-JC-Dra-Karen-Luise-Pinheiro.pdf. Acesso em: 14 maio 2019).

17 BRASIL. Retrato das desigualdades de gênero e raça. [2016?]. Disponível em: http://www.ipea.gov.br/retrato/index.html. Acesso em: 22 maio 2019.

${ }^{18}$ DEPARTAMENTO INTERSINDICAL DE ESTATÍSTICA E ESTUDOS SOCIOECONÔMICOS (DIEESE). A inserção da população negra no mercado de trabalho entre 2011 e 2017. 2018. Disponível em: https://www.dieese.org.br/analiseped/2018/2018pednegrospoa.html. Acesso em: 22 maio 2019.

${ }^{19}$ BENTO, Maria Aparecida da Silva. A mulher negra no mercado de trabalho. Revista Estudos Feministas, v. 3, n. 2, p. 479-488, 1995. Doi: https://doi.org/10.1590/\%25x.

${ }^{20}$ SANTOS, Walkyria Chagas da Silva. A mulher negra brasileira. Revista África e Africanidades, ano 2, n. 5, maio 2009. Disponível em: http://www.africaeafricanidades.com.br/documentos/A_mulher _negra_brasileira.pdf. Acesso em: 22 maio 2019.
} 
relação à renda e ao acesso ao trabalho, estão mais próximas dos padrões de oportunidades dos homens brancos, nesse caso são as mulheres negras que integram a posição mais pauperizada da população. ${ }^{21}$

Segundo Flávia Biroli ${ }^{22}$, as mulheres negras estão na posição de maior desvantagem em relação ao trabalho precarizado: "Elas são 39\% das pessoas que exercem esse tipo de trabalho, seguidas pelos homens negros $(31,6 \%)$, pelas mulheres brancas $(27 \%)$ e, por fim, pelos homens brancos $(20,6 \%)$ ). Tais dados demonstram a realidade injusta que as mulheres negras vivenciam, mediante condições vulneráveis no mercado de trabalho, o que acaba por reforçar as diferenças e demonstra que o preconceito de gênero e raça continua perdurando no Brasil. Reconhece-se assim que as ocupações mais precárias são ocupadas por mulheres negras.

De acordo com o exemplo da feminista Kimberlé ${ }^{23}$,

\begin{abstract}
em alguns mercados de trabalho, especialmente aqueles segregados por gênero e raça, as mulheres racializadas podem se confrontar com a discriminação composta, onde, como regra, as mulheres sejam contratadas para funções de escritório ou posições que envolvem interação com o público, enquanto que as minorias étnicas ou raciais sejam empregadas no trabalho industrial ou em alguma outra forma de trabalho segregado por gênero. Nesses casos, mulheres racializadas enfrentam discriminação porque os empregos femininos não são apropriados para elas e o trabalho designado para homens racializados é definido como inapropriado para mulheres.
\end{abstract}

Assim, faz-se necessário destacar que a presença do racismo e do machismo dificulta o ingresso e a ocupação das mulheres negras em cargos formais, qualificados e com melhores condições de remuneração salarial.

Karen Pinheiro ${ }^{24}$, um grande exemplo de magistrada negra do estado do Rio Grande do Sul, relata a respeito dos desafios enfrentados na sua trajetória profissional enquanto juíza, apontando a presença do racismo em diversos setores da carreira jurídica, conforme menciona:

Ao longo desses anos não foi fácil trabalhar em comunidades erigidas por intermédio da economia escravocrata, nas quais as riquezas foram acumuladas com

\footnotetext{
${ }^{21}$ BIROLI, Flávia, Gênero e desigualdades: limites da democracia no Brasil. São Paulo: Boitempo, 2018. p. 22.

22 Ibid.

${ }^{23}$ CRENSHAW, Kimberlé. Documento para o encontro de especialistas em aspectos da discriminação racial relativos ao gênero. Estudos Feministas, p. 171-188, 2002. Disponível em: http://www.scielo.br/pdf/ref/v10n1/11636.pdf. Acesso em: 9 maio 2019. p. 179.

${ }^{24}$ PINHEIRO, Karen L. V. B. de Souza. Uma magistrada negra: história e um Judiciário para além da exceção. Carta Capital, 21 mar. 2019. Disponível em: https://www.cartacapital.com.br/blogs/sororidade-em-pauta/umamagistrada-negra-historia-e-um-judiciario-para-alem-da-excecao/. Acesso em: 7 maio 2019.
} 
a exploração da força de trabalho, dos corpos e das vidas de negros e negras. [...] Enfrentei a dura realidade de dizer o direito para quem há pouco mais de cem anos sequer reconhecia humanidade em indivíduos negros - os arranjos sociais consolidados ainda não permitem à sociedade enxergar-nos como sujeitos dos mesmos direitos, aptos ao exercício de função tão relevante como a da magistratura.

Para a juíza, inúmeras pessoas surpreendem-se com a imagem de uma mulher negra exercendo a jurisdição, o que mostra que em pleno século XXI ainda há trabalhos para negros e trabalhos para brancos, há espaços para negros e espaços para brancos, o que confirma o processo discriminatório. A juíza complementa:

\begin{abstract}
Acredito que transformações somente poderão ocorrer por intermédio de inclusão de pautas antirracistas em todas as esferas de poder, com ampla participação da população, construindo-se políticas públicas de solidariedade, para que os descendentes de escravizados efetivamente emancipem-se. ${ }^{25}$
\end{abstract}

Nos padrões atuais da sociedade, as mulheres negras são posicionadas como uma classe direcionada a ocupações específicas e com um salário menor remunerado que os homens e mulheres brancas, mesmo que desempenhem atividades iguais e tenham um grau de escolaridade equivalente. Essa realidade expõe a discriminação de gênero e raça no ambiente de trabalho ainda existente.

\title{
2.2. Os movimentos de luta da mulher negra no Brasil e o direito no ambiente de trabalho
}

O feminismo ${ }^{26}$ é um movimento que luta pela garantia da igualdade dos direitos sociais e políticos. Devido a ele, surgiu a importância e relevância de criar algumas vertentes específicas para determinados grupos de mulheres, sendo uma delas o feminismo negro, que nasceu em virtude das discussões sobre as dimensões de gênero e raça. ${ }^{27}$

\footnotetext{
25 Ibid.

${ }^{26}$ É importante frisar que empoderamento e feminismo negro são conceitos distintos, porém interligados, sendo um a consequência do outro. Enquanto o feminismo negro é um movimento social que busca pela igualdade de gênero, o empoderamento é uma ação coletiva, o ato de conceder poder para si e para outras mulheres (LUDOVICO, Tânia. A diferença entre o empoderamento feminino e o feminismo. 2018. Disponível em: https://aempreendedora.com.br/a-diferenca-entre-o-empoderamento-feminino-e-o-feminismo/. Acesso em: 14 maio 2019).

${ }^{27}$ RIBEIRO, Djamila. Quem tem medo do feminismo negro? São Paulo: Companhia de Letras, 2018. p. 53.
} 
O feminismo negro no Brasil começou a ganhar força a partir de $1980^{28}$, tendo como um dos grandes nomes Lélia Gonzalez, que foi a percursora que revolucionou o movimento feminista negro no Brasil, pois manifestou as lutas das mulheres negras, apontando os problemas enfrentados na sociedade brasileira, como o racismo e sexismo. A ativista marcou um papel de suma importância no país, levando em conta sua voz perante as reivindicações. ${ }^{29}$

Os movimentos sociais das mulheres negras ${ }^{30}$ são marcados pelo fortalecimento da luta pelos direitos da população negra, pois a ideologia do movimento foi criada basicamente para a construção de prerrogativas, levando em conta a realidade injusta e a geração de fatores opressores. Reporta na concepção de que os movimentos estimularam composições de projetos para transformações de classes oprimidas, ficando estabelecidas as lutas das minorias sociais. $^{31}$

No momento atual, as lutas das mulheres negras permanecem em busca de condições de igualdades sociais, fortalecendo a construção das categorias de raça e gênero no espaço social. ${ }^{32}$ Angela Davis afirma a relevância dos movimentos das mulheres negras: "Nós representamos as poderosas forças de mudança que estão determinadas a impedir que as moribundas culturas do racismo e do patriarcado heterossexual se ergam novamente". ${ }^{33}$

Angela Davis é uma ativista norte-americana conhecida por ser um ícone no feminismo negro, visto que atua na luta e defesa dos direitos das mulheres negras e no

\footnotetext{
28 "Segundo a socióloga Núbia Moreira, a relação das mulheres negras com o movimento feminista estabelece a partir do 111 Encontro Feminista Latino-Americano ocorrido em Bertioga em 1985, de onde emerge a organização atual de mulheres negras com expressão coletiva com o intuito de adquirir visibilidade política no campo feminista. A partir daí, surgem os primeiros coletivos de mulheres negras, época em que aconteceram alguns encontros estaduais e nacionais de mulheres negras. Em momentos anteriores, porém, há vestígios de participação de mulheres negras no Encontro Nacional de Mulheres, realizado em março de 1979. No entanto, a nossa compreensão é que, a partir do encontro ocorrido em Bertioga, se consolida entre as mulheres negras um discurso feminista, uma vez que em décadas anteriores havia uma rejeição por parte de algumas mulheres negras em aceitar a identidade feminista" (Ibid., p. 52).

${ }^{29}$ HOJE na História, 1935, nascia Lélia Gonzalez. 2012. Disponível em: https://www.geledes.org.br/hoje-nahistoria-1935-nascia-lelia-gonzalez/. Acesso em: 20 set. 2018.

${ }^{30}$ Galedés - Instituto da Mulher negra é uma organização política brasileira das mulheres negras, fundada em 30 de abril de 1988, que tem como objetivo principal a luta contra o racismo e sexismo presentes na sociedade. Atualmente, a organização desenvolve projetos na defesa dos direitos humanos, priorizando a questão racial e gênero nas áreas da educação, saúde, comunicação e mercado de trabalho; Movimento negro unificado é uma organização fundada no dia 18 de junho de 1978 e lançada publicamente no dia 7 de julho de 1978, em pleno regime militar, tendo como objetivo a luta contra a discriminação racial no país.

${ }^{31}$ MARQUES, Geisa. Estatuto da Igualdade Racial fortalece luta das mulheres negras. 2018. Disponível em: http://www.pt.org.br/estatuto-da-igualdade-racial-fortalece-luta-das-mulheres-negras/. Acesso em: 23 set. 2018.

${ }^{32}$ CARVALHO, Rayssa Andrade; ROCHA, Solange Pereira. Movimento de mulheres negras e a luta pela afirmação dos direitos humanos no Brasil. Cadernos Imbondeiro, v. 2, n. 1, 2012.

${ }^{33}$ DAVIS, Angela. A vida e a luta de Angela Davis, desde os anos 1960 até o discurso na Marcha das Mulheres nos EUA. 2017. Disponível em: https://www.hypeness.com.br/2017/01/a-vida-e-a-luta-de-angeladavis/. Acesso em: 22 set. 2018.
} 
combate da discriminação racial e social. Sua contribuição histórica busca esclarecer a luta política desse movimento. Atualmente, sua trajetória é específica ao movimento feminista negro, LGBT e discussão sobre a política de cárcere. ${ }^{34}$

Entretanto, a luta das mulheres negras representa uma batalha contínua sobre a igualdade de direitos, tendo em vista a presença de desigualdade e discriminação de gênero e raça no mercado de trabalho, assim o movimento busca romper com as diferenças sofridas pelas afrodescendentes. Pode-se verificar e analisar a trajetória da mulher negra no trecho abaixo:

\begin{abstract}
Enegrecendo o feminismo é a expressão que vimos utilizando para designar a trajetória das mulheres negras no interior do movimento feminista brasileiro. Buscamos assinalar, com ela, a identidade branca e ocidental da formulação clássica feminista, de um lado; e de outro, revelar a insuficiência teórica e prática política para integrar as diferentes expressões do feminino construído em sociedades multirraciais e pluriculturais. Com essas iniciativas, pôde-se engendrar uma agenda específica que combateu, simultaneamente, as desigualdades de gênero e intragênero; afirmamos e visibilizamos uma perspectiva feminista negra que emerge da condição específica do ser mulher, negra e, em geral, pobre, delineamos, por fim, o papel que essa perspectiva tem na luta antirracista no Brasil. ${ }^{35}$
\end{abstract}

Percebe-se que a luta das mulheres negras para conquistar pequenos espaços na sociedade, batalhando pelos mesmos ideais, buscando a igualdade profissional de gênero e raça, ainda que seja árdua, segue em seu propósito com relação às mudanças. Em um contexto geral, entende-se que as mulheres negras conseguiram alcançar espaço no ambiente de trabalho, porém a inserção se dá de forma injusta e desigual em vista dos fatores de preconceito da raça e classe, isso porque sofrem por serem socialmente excluídas.

Pode-se afirmar que o mercado de trabalho brasileiro, em que pese a existência de mulheres negras, é influenciado pelas opressões intersectadas de raça, gênero e classe, pois elas não só ingressam menos no mercado de trabalho, mas ingressam em locais fixos, estereotipados e ainda mais explorados. ${ }^{36}$

\footnotetext{
${ }^{34}$ ANGELA Davis completa 73 anos. [2017?]. Disponível em: http://todosnegrosdomundo.com.br/an gela-davis-completa-73-anos/. Acesso em: 9 jun. 2019.

${ }^{35}$ CARNEIRO, Sueli. Mulheres em movimento. Estudos Avançados, São Paulo, v. 17, n. 49, 2003. Doi: http://dx.doi.org/10.1590/S0103-40142003000300008. p. 118.

${ }^{36}$ BUENO, Winnie. Mulheres negras e trabalho - considerações a partir do pensamento de Patricia Hill Collins. 2018. Disponível em: https://medium.com/@ winniebueno/mulheres-negras-e-trabalhoconsidera\%C3\%A7\%C3\%B5es-a-partir-do-pensamento-de-patricia-hill-collins-pt1-1d90e14cadef. Acesso em: 22 maio 2019.
} 
A filósofa Djamila Ribeiro ${ }^{37}$ expõe que sofreu discriminação no mercado de trabalho pelo fato de ser mulher negra e ressalta a importância do papel da mulher negra na teoria feminista ao questionar o patriarcado racista:

\begin{abstract}
Depois de passar na faculdade de jornalismo, comecei a procurar um emprego. Apesar de falar inglês, ser medalhista de xadrez e ter recebido prêmios escolares, uma amiga da minha mãe me ofereceu uma vaga de auxiliar de serviços gerais na empresa de que era gerente para me ajudar. Eu limpava e servia café, mesmo tendo currículo melhor do que os das moças que trabalhavam no escritório.
\end{abstract}

Por essa razão, as lutas sociais ensejam a redução de desigualdades sociais, as quais ainda persistem a padrões diferenciados da participação da mulher negra no mercado de trabalho. Embora possam elas possuir um desempenho educacional elevado, ainda enfrentam desafios, seus salários são inferiores aos dos homens e sua participação no comando de chefia até então é restrita. ${ }^{38}$ Isso ocorre porque os padrões hegemônicos de poder estão fortemente presentes na sociedade brasileira e reforçam padrões institucionais.

No que concerne ao direito do trabalho, a Consolidação das Leis do Trabalho (CLT), promulgada em 1943, estabeleceu em seu Capítulo 111 normas específicas para tratar sobre a proteção ao trabalho da mulher, concedendo a igualdade entre homens e mulheres. ${ }^{39}$ Isso estabeleceu um grande avanço ao abrir portas para a independência feminina.

Especificamente as normas de direito do trabalho são resultado de manifestos sociais, os quais possuem objetivo de garantir inserção e condições de igualdade de todos, assegurando a equidade nas relações de trabalho. ${ }^{40}$ Dessa forma, garante-se que os direitos fundamentais constitucionalmente assegurados sejam respeitados.

$\mathrm{O}$ artigo da $\mathrm{CLT}^{41}$ menciona:

Art. 373-A. Ressalvadas as disposições legais destinadas a corrigir as distorções que afetam o acesso da mulher ao mercado de trabalho e certas especificidades estabelecidas nos acordos trabalhistas, é vedado:

\footnotetext{
${ }^{37}$ RIBEIRO, Djamila. Quem tem medo do feminismo negro? São Paulo: Companhia de Letras, 2018. p. 13.

${ }^{38}$ MARCONDES, Mariana Mazzini et al. Dossiê mulheres negras: retrato das condições de vida das mulheres negras no Brasil. Brasília, DF: Ipea, 2013. Disponível em: http://ipea.gov.br/portal/images/stories/PDFs/livros/livros/livro_dossie_mulheres_negras.pdf. Acesso em: 14 maio 2019. p. 54.

39 LAZZARIN, Helena Kugel. As insuficiências legais relativas ao trabalho da mulher e tratamento igualitário no Brasil. 2016. Dissertação (Mestrado em Direito) - Universidade do Vale dos Sinos, 2016. p. 78.

40 RELAÇÃO trabalhista: entenda os direitos da mulher! 2017. Disponível em: https://www.metadados.com.br/blog/relacao-trabalhista-entenda-os-direitos-da-mulher/. Acesso em: 7 jun. 2019.

41 BRASIL. Decreto-lei n. 5.452, de $1^{\circ}$ de maio de 1943. Aprova a Consolidação das Leis do Trabalho. Disponível em: http://www.planalto.gov.br/ccivil_03/decreto-lei/del5452.htm. Acesso em: 22 maio 2019.
} 
II- recusar emprego, promoção ou motivar a dispensa do trabalho em razão de sexo, idade, cor, situação familiar ou estado de gravidez, salvo quando a natureza da atividade seja notória e publicamente incompatível;

III- considerar o sexo, a idade, a cor ou situação familiar como variável determinante para fins de remuneração, formação profissional e oportunidades de ascensão profissional; [...].

O dispositivo do referido capítulo estabelece a adoção de medidas da proteção da mulher no ambiente de trabalho, vedando qualquer tipo de desigualdade e discriminação em relação ao aspecto profissional e salarial.

Em conformidade, o artigo $5^{\circ}, \mathrm{XLI}$, da CF/1988 ${ }^{42}$ manifesta-se no sentido de que "a lei punirá qualquer discriminação atentatória dos direitos e liberdades fundamentais", assim como o artigo $7^{\circ}, \mathrm{XXX}$, que veda qualquer tipo de discriminação no trabalho: "XXXproibição de diferença de salários, de exercício de funções e de critério de admissão por motivo de sexo, idade, cor ou estado civil".

Observa-se que os artigos da CLT e os da CF/1988 apresentam normas que proíbem qualquer forma de discriminação e tratamento desigual de homens e mulheres, porém os dispositivos que vedam qualquer tipo de discriminação não preveem efetivas sanções àqueles que cometem atos discriminatórios. ${ }^{43}$

Nessa perspectiva, levando-se em conta os motivos históricos e culturais, mulheres negras continuam sendo tratadas de forma desigual e discriminatória, permanecendo em situação de inferioridade nos ambientes de trabalho. Diante dessas circunstâncias, verifica-se que as leis trabalhistas são omissas quanto ao direito da mulher negra, por esse motivo que os movimentos sociais são significativos para lutar pelos direitos trabalhistas.

A população negra, em geral, sofre discriminação no Brasil desde o período colonial até o período atual, por isso é cada vez mais latente a necessidade de buscar meios de diminuir essas diferenças.

\section{Perspectiva de gênero, raça e classe no ordenamento jurídico}

Os problemas discutidos pelo movimento feminista, de busca pela superação das opressões, estão relacionados com as desigualdades na concepção de gênero, raça e classe. A

\footnotetext{
${ }^{42}$ Id. [Constituição (1988)]. Constituição da República Federativa do Brasil. Brasília, DF, 1988. Disponível em: http://www.planalto.gov.br/ccivil_03/constituicao/constituicaocompilado.htm. Acesso em: 4 maio 2019.

${ }^{43}$ LAZZARIN, Helena Kugel. As insuficiências legais relativas ao trabalho da mulher e tratamento igualitário no Brasil. 2016. Dissertação (Mestrado em Direito) - Universidade do Vale dos Sinos, 2016. p. 83.
} 
questão é analisada entre as décadas de 1960 e 1970, período em que se iniciaram os movimentos sobre o feminismo negro, estudos sobre as especificidades da mulher negra como sujeito e a definição das relações dessas classes sociais. ${ }^{44}$

O entendimento com relação a gênero, raça e classe tem como pressuposto o estudo da intersecionalidade, categoria que tem como mentora a feminista Kimberlé Williams Crenshaw, que define o tema como "formas de capturar as consequências da interação entre duas ou mais formas de subordinação: sexismo, racismo, patriarcalismo". ${ }^{4}$

A intersecionalidade, segundo a autora,

[...] é uma conceituação do problema que busca capturar as consequências estruturais e dinâmicas da interação, entre dois ou mais eixos da subordinação. Ela trata especificamente da forma pela qual o racismo, o patriarcalismo, a opressão de classe e outros sistemas discriminatórios criam desigualdades básicas que estruturam as posições relativas de mulheres, raças, etnias, classes e outras. Além disso, a intersecionalidade trata da forma como ações e políticas específicas geram opressões que fluem ao longo de tais eixos, constituindo aspectos dinâmicos ou ativos do desempoderamento. $^{46}$

A compreensão sobre a ideia de intersecionalidade mencionada por Kimberlé Crenshaw é justamente a intercessão de identidade entre diversas opressões. A feminista tem como base um estudo sobre os problemas que as mulheres negras enfrentam, enfatizando questões de classes nos discursos acerca dos direitos humanos, garantindo exclusão de violações de direitos humanos das mulheres. ${ }^{47}$

Completando o estudo sobre gênero e raça, Carla Akotinere ${ }^{48}$ esclarece sobre o conceito:

[...] frequentemente e por engano, pensamos que a intersecionalidade é apenas sobre múltiplas identidades, no entanto, a intersecionalidade é, antes de tudo, lente analítica sobre a interação estrutural em seus efeitos políticos e legais. A intersecionalidade nos mostra como e quando mulheres negras são discriminadas e

\footnotetext{
${ }^{44}$ SANTANA, Bianca. Gênero, raça e classe: categorias de análise para compreender (não só) as mulheres negras. 2016. Disponível em: https://www.ceert.org.br/noticias/genero-mulher/11378/genero-raca-e-classecategorias-de-analise-para-compreender-nao-so-as-mulheres-negras. Acesso em: 29 set. 2018.

45 O CONCEITO de "Intersecionalidade". 2015. Disponível em: http://www.sociologia.com.br/o-conceito-deinterseccionalidade/. Acesso em: 29 set. 2018.

${ }^{46}$ CRENSHAW, Kimberlé. Documento para o encontro de especialistas em aspectos da discriminação racial relativos ao gênero. Estudos Feministas, p. 171-188, 2002. Disponível em: http://www.scielo.br/pdf/ref/v10n1/11636.pdf. Acesso em: 9 maio 2019. p. 177.

${ }^{47}$ Ibid., p. 8.

${ }^{48}$ Apud LEAL, Luana Angelo. Desigualdade e discriminação da mulher negra no mercado de trabalho brasileiro: uma análise sociojurídica. 2018. Monografia (Graduação em Direito) - Universidade Federal do Rio de Janeiro, 2018. p. 25.
} 
estão mais vezes posicionadas em avenidas identitárias, que farão delas vulneráveis à colisão das estruturas e fluxos modernos.

Nesse ponto, importa compreender que, segundo o entendimento de Kimberlé Crenshaw, se deve conhecer e implementar mecanismos que garantam, respectivamente, a eliminação da discriminação de raça e gênero. Com relação às mulheres negras, verifica-se promover a necessidade de políticas a serem desenvolvidas para eliminar qualquer tipo de desigualdade racial e de gênero. O desafio da intersecionalidade proposto pela autora é exatamente discutir questões que visam à proteção contra a discriminação de gênero enfrentada por mulheres negras, para que elas possam ser protegidas da mesma forma que mulheres brancas diante de violações sofridas. ${ }^{49}$ Nesse sentido, Crenshaw ${ }^{50}$ expõe sobre a ligação entre as discriminações:

Trata-se da combinação entre a discriminação racial (somente homens negros eram contratados para trabalhar nas linhas de montagem) e a discriminação de gênero (somente brancas eram contratadas para funções consideradas femininas). Portanto, as mulheres negras são afetadas, de maneira específica, pela combinação dessas duas formas diferentes de discriminação.

Com o propósito de esclarecer alguns pontos sobre a intersecionalidade, Kimberlé traz como exemplo um caso prático em que expõe problemas de discriminação enfrentados por mulheres negras no mercado de trabalho. O caso sucedeu-se em virtude de não haver oportunidade de emprego para mulheres afro-americanas, em razão disso foi interposto um processo, movido pela empresa De Graffen Reed contra a General Motors, nos Estados Unidos, alegando a discriminação racial e de gênero. No entanto, o Tribunal não reconheceu a discriminação racial mista, e a decisão foi fundamentada no sentido de que as mulheres deveriam provar primeiro a discriminação racial e após a discriminação de gênero. A ativista fez uma declaração importante em relação à decisão do Tribunal:

Precisamos, portanto, identificar melhor o que acontece quando diversas formas de discriminação se combinam e afetam as vidas de determinadas pessoas. Por essas razões, quando falo sobre intersecionalidade, inicialmente me concentro na noção dos eixos ou das ruas. ${ }^{51}$

\footnotetext{
${ }^{49}$ CRENSHAW, Kimberlé. A intersecionalidade na discriminação de raça e gênero. 2015. Disponível em: http://www.acaoeducativa.org.br/fdh/wp-content/uploads/2012/09/Kimberle-Crenshaw.pdf. Acesso em: 18 abr. 2019. p. 8.

${ }_{51}^{50}$ Ibid., p. 13.

${ }^{51}$ Ibid., p. 8-9.
} 
Resta evidente a dificuldade enfrentada em demandas referentes à discriminação pela falta de reconhecimento do conflito racial presente na sociedade.

A ideia sobre a intersecionalidade provocada pelo movimento feminista negro e por Kimberlé consiste no nível relevante de discriminação que as mulheres negras sofrem em razão de gênero e de raça, além das diferenças de classe social. Entretanto, o ordenamento jurídico possui como direito fundamental a diminuição das desigualdades, considerando as condições em que as mulheres negras se encontram e suas principais consequências. O que se evidencia atualmente é a necessidade de aplicação de políticas públicas para a proteção da mulher negra, além do trabalho em prol da erradicação, que é um processo para eliminar a discriminação institucional muito presente na sociedade brasileira.

\subsection{Identidade da mulher negra}

"Identidade negra" é a expressão utilizada para denominar negros, negras, pardos e pardas descendentes de negros, portanto a identidade é usada para diferenciar um indivíduo perante os seus semelhantes, ou seja, cada indivíduo inserido na sociedade possui suas próprias características. ${ }^{52}$ É importante definir esse conceito, pois a caracterização da mulher negra analisa o contexto social em que ela se encontra, uma vez que a identidade está vinculada em torno de valores considerados socialmente negativos, mantidos pelo preconceito e pela discriminação racial. ${ }^{53}$

No Brasil, o indivíduo negro é diferenciado pelos traços fenotípicos, isto é, seus traços físicos, como cabelos crespos, formato do nariz, boca, entre outros. Assim, faz-se a diferenciação de ser ou não negra e, portanto, suas identificações fazem parte dos processos históricos, culturais, sociais e políticos. ${ }^{54}$ São essas características fenotípicas que determinam como as pessoas negras serão tratadas no âmbito social, pois quanto mais pigmentada uma

\footnotetext{
${ }^{52}$ FARIAS, Jordão. A identidade negra e sua construção: definições e problemáticas. 2018. Disponível em: https://medium.com/@ fariasjordao/a-identidade-negra-e-sua-constru\%C3\%A7\%C3\%A3o-um-resumo-sobredefini\%C3\%A7\%C3\%B5es-e-problem\%C3\%A1ticas-7337056f94b. Acesso em: 30 maio 2019.

${ }^{53}$ FERREIRA, Ricardo Frankllin; CAMARGO, Amilton Carlos. As relações cotidianas e a construção da identidade negra. Psicologia: Ciência e Profissão, v. 31, n. 2, p. 374-389, 2011. Disponível em: http://www.scielo.br/pdf/pcp/v31n2/v31n2a13.pdf. Acesso em: 30 maio 2019.

54 PEREIRA, Lília Campos. A construção da identidade da mulher negra no Brasil. In: CONGRESO INTERNACIONAL DE HUMANIDADES, PALABRA Y CULTURA EN AMÉRICA LATINA: HERENCIAS Y DESAFÍOS, XV, 2012. Anais... 2012. p. 37.
} 
pessoa, mais exclusão e discriminação ela sofrerá na sociedade que, historicamente, é racista e que, portanto, não poderá desfrutar dos mesmos direitos que uma pessoa branca. ${ }^{55}$

Há um vasto debate sobre a identificação fenotípica no Brasil, pois a população é caracterizada pela miscigenação, conceito este que define a mistura de etnias humanas, brancos europeus colonizadores, negros vindos da África e os indígenas presentes no país. ${ }^{56}$

Considerando essa perspectiva, o movimento feminista negro vem trabalhando para melhorar a representação da mulher negra em todos os contextos sociais, lutando pela defesa da democracia e contra o racismo estrutural.

\title{
3.2 Violações de direitos humanos das mulheres negras
}

O propósito da luta das mulheres vai além, e sua proteção tem como aliada a normativa internacional de direitos humanos ${ }^{57}$ em prol de categorias do feminismo negro, pois elas resistiram à discriminação racial, de gênero e classe, o que demonstra que essas implicações requerem uma certa proteção e alicerce para invocar os movimentos sociais. As prerrogativas para ampliar a defesa dos direitos humanos têm o compromisso de contribuir para a instituição de direitos fundamentais em âmbito brasileiro. Tendo em vista os procedimentos adotados para obter proteção de direitos, Flávia Piovesan ${ }^{58}$ manifestou-se nesse sentido:

\begin{abstract}
No âmbito jurídico-normativo, o período pós-1988 é marcado pela adoção de uma ampla normatividade nacional voltada à proteção dos direitos humanos, ao que se conjuga a crescente adesão do Brasil aos principais tratados internacionais de proteção dos direitos humanos. A Constituição Federal de 1988 celebra, deste modo, a reinvenção do marco jurídico normativo brasileiro no campo da proteção dos direitos humanos.
\end{abstract}

Após o período de 1988, o Brasil, além de assinar documentos que reconhecem as proteções dos direitos humanos das mulheres, apresentou avanço legislativo no que se refere à

\footnotetext{
55 DJOKIC, Aline. Colorismo: o que é, como funciona. 2015. Disponível em: https://www.geledes.org.br/colorismo-o-que-e-como-funciona/. Acesso em: 22 maio 2019.

56 MELO, Priscila. Miscigenação no $\quad$ Brasil. $2014 . \quad$ Disponível em: https://www.estudopratico.com.br/miscigenacao-no-brasil/. Acesso em: 23 maio 2019.

57 "THEMIS - Gênero, Justiça e Direitos Humanos é uma organização da sociedade civil com sede em Porto Alegre, criada em 1993, com o objetivo fortalecer o conhecimento das mulheres sobre seus direitos e o sistema de justiça e fortalecer o enfrentamento as desigualdades raciais, socioeconômicas e culturais" (THEMIS Gênero, Justiça e Direitos Humanos. História. [2019?]. Disponível em: http://themis.org.br/somos/historia/. Acesso em: 14 maio 2019).

${ }^{58}$ PIOVESAN, Flávia. Temas de direitos humanos. 4. ed. São Paulo: Saraiva, Leila Linhares, 2010. p. 280.
} 
igualdade de direitos entre homens e mulheres. ${ }^{59}$ Ademais, a Organização das Nações Unidas (ONU) aderiu à Convenção sobre a Eliminação de todas as formas de Discriminação Racial, com o objetivo de eliminar a discriminação racial para que se garanta o pleno exercício de direitos civis, políticos, sociais, econômicos e culturais. $\mathrm{O}$ artigo $1^{\circ}$ da Convenção apresenta o combate à discriminação, implementando igualdades dos direitos humanos e liberdades fundamentais, conforme cita Piovesan ${ }^{60}$ :

Art. $1^{\circ}$ qualquer distinção, exclusão, restrição ou preferência baseada em raça, cor, descendência ou origem nacional ou étnica, que tenha o propósito ou o efeito de anular ou prejudicar o reconhecimento, gozo ou exercício em pé de igualdade dos direitos humanos e liberdades fundamentais.

De outro modo, foi aprovada pelas Nações Unidas, em 1975, a Convenção sobre Eliminação de todas as formas de Discriminação contra a mulher, que impõe igualdade entre homens e mulheres e elimina a discriminação. Essa Convenção presume possibilidades de adoção de ações em que prevaleçam o princípio da igualdade. $O$ artigo $1^{\circ}$ expõe a obrigatoriedade de eliminar o preconceito e promover estratégias para assegurar a igualdade:

\begin{abstract}
Art. $1^{\circ}$ toda distinção, exclusão ou restrição baseada no sexo e que tenha por objeto ou resultado prejudicar ou anular o reconhecimento, gozo, exercício pela mulher, independentemente de seu estado civil, com base na igualdade do homem e da mulher, dos direitos humanos e das liberdades fundamentais nos campos político, econômico, social, cultural e civil ou em qualquer outro campo. ${ }^{61}$
\end{abstract}

Destaca-se que, no cenário internacional, agregou-se à Conferência de Viena, que tem como finalidade a proteção internacional dos direitos humanos das mulheres e como princípio o reconhecimento universal do direito à igualdade, afastando todas as formas de discriminação contra a mulher. ${ }^{62}$

No Brasil, além da Constituição Federal de 1988, o Estatuto da Igualdade Racial foi promulgada com o intuito de proporcionar uma nova leitura para o princípio da igualdade. ${ }^{63} \mathrm{O}$

\footnotetext{
${ }^{59}$ Ibid., p. 280.

${ }^{60}$ PIOVESAN, Flávia. Direitos humanos e o direito constitucional internacional. 11. ed., ver. e atual. São Paulo: Saraiva, 2010.

${ }^{61}$ Ibid., p. 293-295.

${ }^{62}$ PIOVESAN, Flávia. Direitos humanos e o direito constitucional internacional. 11. ed., ver. e atual. São Paulo: Saraiva, 2010.

${ }^{63}$ SIMÃO, Calil (coord.). Estatuto da igualdade racial: comentários doutrinários. Leme, SP: J. H. Mizuno, 2011.p. 41
} 
autor do projeto, o senador Paulo Paim ${ }^{64}$, expõe sobre o compromisso e os principais propósitos sobre a aprovação do Estatuto:

\begin{abstract}
Não queremos a cultura afro-brasileira vista, sentida e experimentada somente nas práticas religiosas, música ou alimentação. Queremos a cultura do negro inserida nas escolas, no mercado de trabalho, nas universidades, pois o negro faz parte do povo brasileiro. Cultivar as raízes da nossa formação histórica evidentes na diversificação da composição étnica do povo é o caminho mais seguro para garantirmos a afirmação de nossa identidade nacional e preservarmos os valores culturais que conferem autenticidade e singularidade ao nosso país. É imprescindível que haja união entre as pessoas, povos, nacionalidades e culturas. Todos os esforços para combater as barreiras discriminatórias são subsídios concretos para a formação de um novo ser humano, capaz de elevar-se à altura de seu destino e evitar destruir a si mesmo.
\end{abstract}

O Estatuto é uma composição de medidas para atender aos interesses da coletividade negra, contribuindo com projetos e ações destinadas a incluir minorias que sempre sofreram com as desigualdades na sociedade brasileira. ${ }^{65}$ Dessa forma, pode-se considerar a importância da produção do Estatuto da Igualdade Racial instituído pela Lei n. 12.288/2010 ${ }^{66}$, que tem como objetivo buscar uma sociedade mais justa, respeitando a dignidade da pessoa humana e seus direitos e garantias fundamentais, proporcionando ações afirmativas e políticas públicas com o intuito de diminuir o tratamento racial desigual. ${ }^{67}$

Em conformidade com o princípio da igualdade elencado na Constituição Federal, o Estatuto da Igualdade Racial oferece garantias à população negra sobre a aplicabilidade da igualdade de oportunidades e defesa de seus direitos étnicos individuais, coletivos e difusos. A regulamentação do Estatuto especifica um artigo voltado à mulher negra em que relata a desigualdade de raça, gênero e cautelas em casos de violações de direitos. A previsão sobre garantias e igualdade à população negra está elencada no artigo $1^{\circ}$, III:

Art. $1^{\circ}$ Esta Lei institui o Estatuto da Igualdade Racial, destinado a garantir à população negra a efetivação da igualdade de oportunidades, a defesa dos direitos étnicos individuais, coletivos e difusos e o combate à discriminação e às demais formas de intolerância étnica.

\footnotetext{
${ }^{64}$ Apud ORUANAN, Cristina de. Diversidade da cultura afro: todos os campos sociais. 2015. Disponível em: http://blocoembaraxe.blogspot.com/2015/08/nao-queremos-culturaafro-brasileira.html. Acesso em: 23 maio. 2019.

${ }^{65}$ SIMÃO, Calil (coord.). Estatuto da igualdade racial: comentários doutrinários. Leme, SP: J. H. Mizuno, 2011. p. 44.

${ }^{66}$ BRASIL. Lei n. 12.288, de 20 de julho de 2010. Institui o Estatuto da Igualdade Racial; altera as Leis nos 7.716, de 5 de janeiro de 1989, 9.029, de 13 de abril de 1995, 7.347, de 24 de julho de 1985, e 10.778, de 24 de novembro de 2003. Disponível em: http://www.planalto.gov.br/ccivil_03/_Ato2007-2010/2010/Lei/L12288.htm. Acesso em: 23 set. 2018 .

${ }^{67}$ SIMÃO, op. cit., p. 281.
} 
Parágrafo único. Para efeito deste Estatuto, considera-se: [...]

III - desigualdade de gênero e raça: assimetria existente no âmbito da sociedade que acentua a distância social entre mulheres negras e os demais segmentos sociais; ${ }^{68}$ $[\ldots]$

Sobre a punição de condutas discriminatórias a grupos determinados em razão de raça, etnia, cor ou procedência nacional, por sua vez, a Lei n. $9.459^{69}$, de 13 de maio de 1997, o qual corrigiu a Lei n. $7.716^{70}$, de 15 de janeiro de 1989, define como crime atos resultantes de preconceito e discriminação. Essa normativa tem como intuito contribuir punições de condutas discriminatórias, visando garantir a harmonia social.

Embora as legislações de proteção, ainda há uma grande preocupação relacionada ao aumento do percentual de mulheres negras que são vítimas das violações dos direitos humanos. Sueli Carneiro ${ }^{71}$, por exemplo, menciona: "Ser mulher negra é ocupar um lugar na sociedade brasileira marcado por múltiplas injunções que se potencializam para sua difícil inserção social"'.

A decorrência de violações de direitos das mulheres negras é resultado do aumento de desigualdades. Apesar das determinações nas legislações específicas que visam à proteção, muitas mulheres continuam sendo vítimas de violações de direitos. ${ }^{72}$

\section{A importância da afirmação de direitos para o empoderamento da mulher negra}

Movimentos organizados de luta das mulheres são históricos pelo mundo, e sua grande maioria reivindica posicionamentos políticos em prol de direitos. $\mathrm{O}$ movimento feminino

\footnotetext{
${ }^{68}$ BRASIL. Lei n. 12.288, de 20 de julho de 2010. Institui o Estatuto da Igualdade Racial; altera as Leis nos 7.716, de 5 de janeiro de 1989, 9.029, de 13 de abril de 1995, 7.347, de 24 de julho de 1985, e 10.778, de 24 de novembro de 2003. Disponível em: http://www.planalto.gov.br/ccivil_03/_Ato2007-2010/2010/Lei/L12288.htm. Acesso em: 23 set. 2018.

69 “Art. $1^{\circ}$ Serão punidos, na forma desta Lei, os crimes resultantes de discriminação ou preconceito de raça, cor, etnia, religião ou procedência nacional” (Id. Lei n. 9.459, de 13 de maio de 1997. Altera os arts. $1^{\circ}$ e 20 da Lei $\mathrm{n}^{\mathrm{o}}$ 7.716, de 5 de janeiro de 1989, que define os crimes resultantes de preconceito de raça ou de cor, e acrescenta parágrafo ao art. 140 do Decreto-lei $\mathrm{n}^{\circ}$ 2.848, de 7 de dezembro de 1940. Disponível em: http://www.planalto.gov.br/ccivil_03/leis/L9459.htm. Acesso em: 22 maio 2019).

${ }^{70} I d$. Lei n. 7.716, de 5 de janeiro de 1989. Define os crimes resultantes de preconceito de raça ou de cor. Disponível em: http://www.planalto.gov.br/ccivil_03/leis/17716.htm. Acesso em: 22 maio 2019.

${ }^{71}$ Apud GALVÃO, Patrícia. Dossiê sobre a situação dos direitos humanos das mulheres negras no Brasil: violências e violações. [2018?] Disponível em: http://latitudeslatinas.com/download/artigos/Dossie-sobre-asituacao-dos-direitos-humanos-das-mulheres-negras-no-Brasil-Violencias-e-Violacoes.pdf. Acesso em: 23 set. 2018.

${ }^{72}$ WERNECK, Jurema Werneck; IRACI, Nilza. A situação dos direitos humanos das mulheres negras no Brasil: violências e violações. 2017. Disponível em: http://fopir.org.br/wp-content/uploads/2017/01/DossieMulheres-Negras-.pdf. Acesso em: 27 set. 2018. p. 39.
} 
negro busca, desde os anos 1960, aproximadamente, ser aceito e, mais além, ter seus direitos igualmente considerados, assim como outros grupos identitários. Esse movimento político de reivindicação de direitos e reconhecimento pelas mulheres negras é chamado empoderamento. O conceito de empoderamento, muitas vezes, é interpretado de forma equivocada, sendo assimilado como algo individual. Portanto, para o feminismo negro, o empoderamento possui uma relevância de coletividade, colocando mulheres negras como sujeitos de mudanças sociais.

Cada mulher pode criar em seu espaço de atuação formas de empoderar outras. Se for empregadora, pode criar um ambiente de trabalho no qual exista o respeito e que possa atender à demanda de mulheres, principalmente daquelas que são mães, além de se certificar de que não há desigualdade salarial e assédio. ${ }^{73}$

Como menciona a feminista Bell Hooks ${ }^{74}$, “o empoderamento diz respeito a mudanças sociais numa perspectiva antirracista, antielitista e sexista através das mudanças das instituições sociais e consciência individuais". Para ela, é necessário criar mecanismos de empoderamento, com a finalidade de reivindicar direitos a humanidade.

Ante essa consideração, é fundamental expor a análise da pensadora Patricia Hill Collins ${ }^{75}$ sobre a aplicação do empoderamento feminino:

Uma afirmação da importância da autodefinição e da autoavaliação das mulheres negras é primeiro tema-chave que permeia declarações históricas e contemporâneas do pensamento feminista negro. Autodefinição envolve desafiar o processo de validação do conhecimento político que resultou em imagens estereotipadas extremamente definidas da condição feminina afro-americana. Em contrapartida, a autoavaliação enfatiza o conteúdo específico das autodefinições das mulheres negras, substituindo imagens extremamente definidas com imagens autênticas de mulheres negras.

Por esse motivo que o processo de empoderamento compromete-se com a luta pela equidade, com o propósito de promover uma sociedade mais justa às mulheres negras, que sobrevivem às práticas do sistema de dominação racista. ${ }^{76}$

Logo, surge a necessidade de estabelecer as principais demandas das mulheres negras para o empoderamento, uma vez que se trata de instrumento importante nas lutas

\footnotetext{
${ }^{73}$ RIBEIRO, Djamila. Quem tem medo do feminismo negro? São Paulo: Companhia de Letras, 2018. p. 135136.

${ }_{74}^{73}$ Apud Ibid.

${ }^{75}$ Apud BERTH, Joice. O que é empoderamento? Belo Horizonte: Letramento: Justificando, 2018. p. 17.

${ }^{76}$ RIBEIRO, Djamila. Quem tem medo do feminismo negro? São Paulo: Companhia de Letras, 2018. p. 135136.
} 
emancipatórias de minorias sociais com a finalidade de reparar os erros históricos e estruturais do racismo brasileiro. ${ }^{77}$

\subsection{Pesquisa sobre a atual realidade da mulher negra no Brasil}

A pesquisa realizada para o presente artigo foi de caráter qualitativo, no qual procurou verificar se as mulheres negras se sentem discriminadas no ambiente de trabalho. Para isso, foi aplicado um questionário qualitativo (Apêndice A) às mulheres integrantes da Comissão Especial da Igualdade Racial da OAB/RS. A escolha pelo grupo se deve à sua representatividade em um espaço institucional de forte atuação social.

A escolha da pesquisa qualitativa teve o intuito de buscar maiores esclarecimentos sobre o assunto, além de destacar a importância de relatos, tendo como base a complexidade dos problemas a fim de compreender detalhadamente os processos sociais os quais estão submetidas as mulheres negras.

Cabe assim identificar que a Comissão Especial da Igualdade Racial instaurada em dezembro de 2018 e orientada pela advogada Karla Meura tem um papel de suma importância na busca de direitos das mulheres negras e discussões sobre gênero e raça. No que se refere à coleta de dados, foram encaminhadas perguntas para seis mulheres negras advogadas inseridas no mercado de trabalho. Esse questionário abordou especificamente temas referentes ao ambiente profissional com a finalidade de compreender como sua trajetória tornou-se importante dentro do movimento por igualdade de direitos.

Os questionamentos realizados desenvolveram-se com base nos seguintes aspectos: constrangimentos sentidos nos locais públicos e privados pelo fato de ser mulher negra; se alguma vez sentiram-se alvo de discriminação no ambiente de trabalho; posteriormente, foi perguntado a respeito de mulheres negras atuarem de forma igualitária tal qual outras mulheres no mercado de trabalho, considerando cargos e salários; e, por fim, se elas reconhecem avanços nas políticas públicas no tocante ao combate à discriminação de gênero e raça em âmbito social no Brasil.

A construção do método de pesquisa, de modo geral, teve o intuito de compreender a trajetória desse grupo específico e demonstrar seus anseios e processos dificultosos para inserção em espaços institucionais, além das dificuldades de inserção no mercado de trabalho.

\footnotetext{
${ }^{77}$ BERTH, Joice. O que é empoderamento? Belo Horizonte: Letramento: Justificando, 2018. p. 42.
} 
As questões foram voltadas a aspectos sobre as discriminações, desigualdade $\mathrm{e}$ as contribuições de políticas públicas para resolver o problema do racismo no ambiente de trabalho.

\subsection{Análise dos resultados}

Diante das respostas referentes à pesquisa realizada com mulheres negras da Comissão referida, elencam-se os principais pontos com base em uma análise no presente capítulo sobre seus principais posicionamentos referentes ao tema abordado. A pesquisa possibilitou compreender que a cor da pele, dependendo do local em que se encontram, causa um constrangimento maior, por isso procuram ser cautelosas ao agir (atitudes simples como ir no supermercado), para não correr o risco de ser acusadas de algum tipo de infração.

No que tange à discriminação no ambiente de trabalho, observa-se que mulheres negras sofrem com esse fato, pois apesar de as entrevistadas serem advogadas (estando em posição de certo modo de "privilégio"), elas relatam que há discriminação tanto nos Foros de Porto Alegre como na Universidade e em audiências no qual trabalham diariamente. Elas citaram, como exemplo, que sempre foram confundidas com a parte reclamante ou requerente, nunca sendo colocadas como advogada ou representante da empresa, assim como que seria uma surpresa para todos encontrar em uma sala de audiências uma advogada, preposta ou juíza negra.

Os problemas levantados revelam a carga histórica e cultural de desigualdades que o Brasil carrega. Mesmo que todas as mulheres sofram com a falta do direito à igualdade, levando-se em consideração também o machismo estrutural da sociedade, no mercado de trabalho a mulher negra leva mais tempo ou sequer chega ao patamar da formalidade.

Devido à incompatibilidade de oportunidades, seus salários ou cargos são inferiores ao das mulheres brancas e, obviamente, inferiores ao dos homens. Desse modo, fica evidente que pesa sobre a mulher negra, além da barreira do gênero, ainda a raça e que, por esse motivo, se encontra na base da pirâmide da discrepância social.

Além disso, o ingresso no mercado de trabalho agrega-se ao critério cor de pele, tipo de cabelo, crença religiosa e influências sociais, com isso a ascensão profissional está ligada diretamente aos padrões físicos. A chance de uma mulher negra conseguir atingir igualdade salarial e de cargos em relação às mulheres brancas é menor e em proporções variáveis. 
Enfim, as pautas do movimento feminista negro são de suma importância, pois apesar de longas, historicamente, estão conquistando mais visibilidade por meio de debates e contribuindo, nos últimos anos, para a criação de políticas públicas. No entanto, é relevante ressaltar, essa realidade ainda está longe do ideal, mas quando comparada com situações anteriores, avançou-se um pouco.

As entrevistadas destacaram que algumas pautas e reivindicações são desconsideradas, principalmente no universo político, o que acaba por dificultar a criação de políticas públicas, visto que esses espaços são ocupados em sua maioria por homens brancos.

Verificou-se, assim, a importância de buscar a expressão de pessoas que se enquadram no assunto pesquisado e evidenciar a realidade da sociedade brasileira.

\section{Considerações Finais}

Diante de todo o exposto, constata-se que as mulheres negras continuam sendo tratadas de forma desigual e discriminatória, devido à herança escravista vinculada pelo racismo estrutural no país. Esse cenário histórico, desde a abolição do trabalho escravo, evidencia as piores condições de trabalho para a mulher negra, dificultando seu acesso, além de receber salários inferiores e piores qualificações profissionais.

O século XXI está chegando no final de sua segunda década, e as mulheres negras continuam sofrendo inúmeros obstáculos dentro do ambiente de trabalho, deixando clara a existência de desigualdade e discriminação de gênero e raça, pois a sociedade brasileira perpetuada pelo racismo ainda não está habituada em ter mulheres negras em cargos de destaque, como juíza, advogada, entre outras profissões.

Essa situação mostra a necessidade de construir uma sociedade justa, ou seja, construir igualdades entre homens e mulheres, respeitando as diferenças existentes entre os indivíduos e reconhecendo seus direitos. Quanto ao ponto referente aos direitos de igualdade e não discriminação analisados, observa-se a urgente necessidade de não determinar tratamentos diferenciados, os quais continuariam a reforçar os processos de desigualdade e ainda perpetrar o estigma da mulher negra como grupo que tem maior vulnerabilidade social.

Verifica-se que existem instrumentos no ordenamento jurídico brasileiro e normas internacionais que ensejam a mudança da situação que as mulheres de modo geral são expostas. Ocorre que, quando se trata de mulheres negras, o nível de proteção da dignidade e 
a aplicabilidade prática das normas não se efetivam em consequência dos motivos históricos e culturais. Ademais, no âmbito da legislação trabalhista, constituíram-se normas regulamentadoras do trabalho da mulher, garantindo igualdade entre gêneros e contribuindo pela diminuição de fatores que causam a discriminação. Nesse sentido, com base no presente estudo, constata-se que não são implantadas medidas efetivas relativas à igualdade da mulher negra no ambiente de trabalho e, principalmente, punições àqueles sujeitos que cometem atos discriminatórios.

Ademais, por intermédio da pesquisa realizada com o grupo de mulheres negras da Comissão Especial da Igualdada Racial, é possível afirmar que o processo de inclusão de mulheres negras continua perpetuando de forma discriminatória e desigual. Constata-se também as dificuldades sofridas para a inserção em ambientes institucionais, bem como no mercado de trabalho em geral, além do meio social.

Dessa forma, as lutas do movimento feminista negro se dão no sentido de fortalecer a luta pelas garantias de direitos fundamentais e chamar a atenção do poder público para a condição de inferioridade que as mulheres negras estão submetidas na atual sociedade, sendo consideradas as maiores vítimas de discriminação racial no ambiente de trabalho e social.

Por fim, é necessária a contribuição do feminismo negro para implantações de políticas públicas que proporcionem ações que promovam a igualdade e inclusão da mulher negra no mercado de trabalho e que adotem medidas cabíveis que sejam capazes de combater a prática de discriminação racial no ambiente de trabalho.

\section{Referências}

ANDRIGHETTO, Aline; OLSSON, Gustavo André. Igualdade e proteção aos direitos das minorias no Brasil. 2014. Disponível em: https://editora.unoesc.edu.br/index.php/espacojuridico/article/view/2810/3493. Acesso em 31 out. 2018.

ANGELA Davis completa 73 anos. [2017?]. Disponível em: http://todosnegrosdomundo.com.br/angela-davis-completa-73-anos/. Acesso em: 9 jun. 2019. 
ARAÚJO, Marcelo. Marcelo Araújo. 2017. Disponível em: http://www.cultura.gov.br/noticias-destaques//asset_publisher/OiKX3xIR9iTn/content/estatuto-da-igualdade-racial-completa-seteanos/10883. Acesso em: 23 set. 2018.

BENTO, Maria Aparecida da Silva. A mulher negra no mercado de trabalho. Revista Estudos Feministas, v. 3, n. 2, p. 479-488, 1995. Doi: https://doi.org/10.1590/\%25x.

BERTH, Joice. O que é empoderamento? Belo Horizonte: Letramento: Justificando, 2018. BIROLI, Flávia, Gênero e desigualdades: limites da democracia no Brasil. São Paulo: Boitempo, 2018.

BRAGATO, Fernanda Frizzo; ADAMATTI, Bianka. Igualdade, não discriminação e direitos humanos: são legítimos os tratamentos diferenciados? Revista de Informação Legislativa, ano 51, n. 204, p. 91-104, out.-dez. 2014. Disponível em: https://www2.senado.leg.br/bdsf/bitstream/handle/id/509929/001032257.pdf?sequence=1. Acesso em: 27. abril 2019.

BRASIL. Retrato das desigualdades de gênero e raça. [2016?]. Disponível em: http://www.ipea.gov.br/retrato/index.html. Acesso em: 22 maio 2019.

Lei n. 12.288, de 20 de julho de 2010. Institui o Estatuto da Igualdade Racial; altera as Leis nos 7.716, de 5 de janeiro de 1989, 9.029, de 13 de abril de 1995, 7.347, de 24 de julho de 1985, e 10.778, de 24 de novembro de 2003. Disponível em: http://www.planalto.gov.br/ccivil_03/_Ato2007-2010/2010/Lei/L12288.htm. Acesso em: 23 set. 2018.

Lei n. 9.459, de 13 de maio de 1997. Altera os arts. $1^{\circ}$ e 20 da Lei $n^{\circ} 7.716$, de 5 de janeiro de 1989, que define os crimes resultantes de preconceito de raça ou de cor, e acrescenta parágrafo ao art. 140 do Decreto-lei $\mathrm{n}^{\circ}$ 2.848, de 7 de dezembro de 1940 . Disponível em: http://www.planalto.gov.br/ccivil_03/leis/L9459.htm. Acesso em: 22 maio 2019

Lei n. 7.716, de 5 de janeiro de 1989. Define os crimes resultantes de preconceito de raça ou de cor. Disponível em: http://www.planalto.gov.br/ccivil_03/leis/17716.htm. Acesso em: 22 maio 2019. 
[Constituição (1988)]. Constituição da República Federativa do Brasil. Brasília,

$\mathrm{DF}$, 1988.

Disponível

em:

http://www.planalto.gov.br/ccivil_03/constituicao/constituicaocompilado.htm. Acesso em: 4 maio 2019.

Decreto-lei n. 5.452, de $1^{\circ}$ de maio de 1943. Aprova a Consolidação das Leis do Trabalho. Disponível em: http://www.planalto.gov.br/ccivil_03/decreto-lei/del5452.htm. Acesso em: 22 maio 2019.

BRITO, Débora. Negros ainda lutam por direitos básicos, 30 anos após Constituição: Constituição de 1988 foi primeira a incluir racismo como crime. 2018. Disponível em: http://agenciabrasil.ebc.com.br/direitos-humanos/noticia/2018-05/negros-ainda-lutam-pordireitos-basicos-30-anos-apos-constituicao. Acesso em: 22 maio 2018.

BUENO, Winnie. Mulheres negras e trabalho - considerações a partir do pensamento de Patricia Hill Collins. 2018. Disponível em: https://medium.com/@winniebueno/mulheresnegras-e-trabalho-considera\%C3\% A7\%C3\%B5es-a-partir-do-pensamento-de-patricia-hillcollins-pt1-1d90e14cadef. Acesso em: 22 maio 2019.

CARNEIRO, Sueli. Mulheres em movimento. Estudos Avançados, São Paulo, v. 17, n. 49, 2003. Doi: http://dx.doi.org/10.1590/S0103-40142003000300008.

CARVALHO, Rayssa Andrade; ROCHA, Solange Pereira. Movimento de mulheres negras e a luta pela afirmação dos direitos humanos no Brasil. Cadernos Imbondeiro, v. 2, n. 1, 2012. CRENSHAW, Kimberlé. A intersecionalidade na discriminação de raça e gênero. 2015. Disponível em: http://www.acaoeducativa.org.br/fdh/wp-content/uploads/2012/09/KimberleCrenshaw.pdf. Acesso em: 18 abr. 2019.

Documento para o encontro de especialistas em aspectos da discriminação racial relativos ao gênero. Estudos Feministas, p. 171-188, 2002. Disponível em: http://www.scielo.br/pdf/ref/v10n1/11636.pdf. Acesso em: 9 maio 2019.

CUSTÓDIO, Tulio. A luta abolicionista e o papel do negro na construção da própria história. 2017. Disponível em: https://www.geledes.org.br/a-luta-abolicionista-e-o-papel-donegro-na-construcao-da-propria-historia/. Acesso em: 20 set. 2018. 
DANDARA; Aqualtune; MAHIN, Luiza. Mulheres negras na luta contra a escravidão no Brasil. 2018. Disponível em: http://www.esquerdadiario.com.br/Dandara-Mulheres-negrasna-luta-contra-a-escravidao-no-Brasil. Acesso em: 20 set. 2018.

DAVIS, Angela. A vida e a luta de Angela Davis, desde os anos 1960 até o discurso na Marcha das Mulheres nos EUA. 2017. Disponível em: https://www.hypeness.com.br/2017/01/a-vida-e-a-luta-de-angela-davis/. Acesso em: 22 set. 2018.

Mulher, raça e classe. Grã-Bretanha: The Women's Press, Ltda., 1982.

DEPARTAMENTO INTERSINDICAL DE ESTATÍSTICA E ESTUDOS SOCIOECONÔMICOS (DIEESE). A inserção da população negra no mercado de trabalho entre 2011 e 2017. 2018. Disponível em: https://www.dieese.org.br/analiseped/2018/2018pednegrospoa.html. Acesso em: 22 maio 2019.

DJOKIC, Aline. Colorismo: o que é, como funciona. 2015. Disponível em: https://www.geledes.org.br/colorismo-o-que-e-como-funciona/. Acesso em: 22 maio 2019.

FARIAS, Jordão. A identidade negra e sua construção: definições e problemáticas. 2018. Disponível em: https://medium.com/@fariasjordao/a-identidade-negra-e-suaconstru\%C3\%A7\%C3\%A3o-um-resumo-sobre-defini\%C3\%A7\%C3\%B5es-eproblem\%C3\%A1ticas-7337056f94b. Acesso em: 30 maio 2019.

FERREIRA, Ricardo Frankllin; CAMARGO, Amilton Carlos. As relações cotidianas e a construção da identidade negra. Psicologia: Ciência e Profissão, v. 31, n. 2, p. 374-389, 2011. Disponível em: http://www.scielo.br/pdf/pcp/v31n2/v31n2a13.pdf. Acesso em: 30 maio 2019.

FLAUZINA, Ana; PIRES, Thula (orgs.). Encrespando. In: SEMINÁRIO INTERNACIONAL: REFLETINDO A DÉCADA INTERNACIONAL DOS AFRODESCENDENTES, I, Brasília, 2016. Brasília: Brado Negro, 2016. Disponível em: http://bradonegro.com/Encrespando.pdf. Acesso em 30 set. 2018. 
GALVÃO, Patrícia. Dossiê sobre a situação dos direitos humanos das mulheres negras no Brasil: violências e violações. [2018?] Disponível em: http://latitudeslatinas.com/download/artigos/Dossie-sobre-a-situacao-dos-direitos-humanosdas-mulheres-negras-no-Brasil-Violencias-e-Violacoes.pdf. Acesso em: 23 set. 2018.

GROSSI, Miriam Pillar; SCHENDEILWEIN, Izabela Liz; MASSA, Jimena Maria. Discriminação tem gênero no brasil. GV-executivo, v. 12, n. 1, jan.-jun. 2013. Disponível em: https://rae.fgv.br/gv-executivo/vol12-num1-2013/discriminacao-tem-generono-brasil. Acesso em: 14 maio 2019.

HOJE na História, 1935, nascia Lélia Gonzalez. 2012. Disponível em: https://www.geledes.org.br/hoje-na-historia-1935-nascia-lelia-gonzalez/. Acesso em: 20 set. 2018.

LAZZARIN, Helena Kugel. As insuficiências legais relativas ao trabalho da mulher e tratamento igualitário no Brasil. 2016. Dissertação (Mestrado em Direito) - Universidade do Vale dos Sinos, 2016.

LEAL, Luana Angelo. Desigualdade e discriminação da mulher negra no mercado de trabalho brasileiro: uma análise sociojurídica. 2018. Monografia (Graduação em Direito) Universidade Federal do Rio de Janeiro, 2018.

LUDOVICO, Tânia. A diferença entre o empoderamento feminino e o feminismo. 2018. Disponível em: https://aempreendedora.com.br/a-diferenca-entre-o-empoderamentofeminino-e-o-feminismo/. Acesso em: 14 maio 2019.

MARCONDES, Mariana Mazzini et al. Dossiê mulheres negras: retrato das condições de vida das mulheres negras no Brasil. Brasília, DF: Ipea, 2013. Disponível em: http://ipea.gov.br/portal/images/stories/PDFs/livros/livros/livro_dossie_mulheres_negras.pdf. Acesso em: 14 maio 2019.

MARQUES, Geisa. Estatuto da Igualdade Racial fortalece luta das mulheres negras. 2018. Disponível em: http://www.pt.org.br/estatuto-da-igualdade-racial-fortalece-luta-dasmulheres-negras/. Acesso em: 23 set. 2018.

MELO, Priscila. Miscigenação no Brasil. 2014. Disponível em: https://www.estudopratico.com.br/miscigenacao-no-brasil/. Acesso em: 23 maio 2019. 
MORENO, Renata (org.). SOF - Sempreviva Organização Feminista. Reflexões e práticas de transformação feminista. São Paulo: SOF, 2015. (Coleção Cadernos Sempreviva. Série Economia e Feminismo, 4).

O CONCEITO de “Intersecionalidade". 2015. Disponível em: http://www.sociologia.com.br/o-conceito-de-interseccionalidade/. Acesso em: 29 set. 2018.

ORUANAN, Cristina de. Diversidade da cultura afro: todos os campos sociais. 2015. Disponível em: http://blocoembaraxe.blogspot.com/2015/08/nao-queremos-culturaafrobrasileira.html. Acesso em: 23 maio. 2019.

PEREIRA, Lília Campos. A construção da identidade da mulher negra no Brasil. In: CONGRESO INTERNACIONAL DE HUMANIDADES, PALABRA Y CULTURA EN AMÉRICA LATINA: HERENCIAS Y DESAFÍOS, XV, 2012. Tema: Valores y creencias en el contexto sociolingüístico y cultural latinoamericano Facultad de Historia, Geografía y Letras. Universidad Metropolitana de Ciencias de la Educación, Santiago de Chile. 17, 18 y 19 de octubre, 2012.Disponível em: file:///D:/Meus\%20documentos/Downloads/653Texto\%20de1\%20art\%C3\%AD_culo-2339-1-10-20170503.pdf. Acesso em 30 set. 2018.

PINHEIRO, Karen L. V. B. de Souza. Uma magistrada negra: história e um Judiciário para além da exceção. Carta Capital, 21 mar. 2019. Disponível em: https://www.cartacapital.com.br/blogs/sororidade-em-pauta/uma-magistrada-negra-historia-eum-judiciario-para-alem-da-excecao/. Acesso em: 7 maio 2019.

PIOVESAN, Flávia. Direitos humanos e o direito constitucional internacional. 11. ed., ver. e atual. São Paulo: Saraiva, 2010.

Temas de direitos humanos. 4. ed. São Paulo: Saraiva, Leila Linhares, 2010.

PIRES, Thula Rafaela de Oliveira. Criminalização do racismo: entre políticos de reconhecimento e meio de legitimação do controle social sobre os negros. Brasília: Brado Negro, 2016.

PORPINO, Henrique Braga. Discriminação de gênero nas relações de trabalho: entre o reconhecimento e a efetividade na equiparação de direitos. Âmbito Jurídico, Rio Grande, v. XXI, n. 171, abr. 2018. Disponível em: http://www.ambitojuridico.com.br/site/?n_link=revista_artigos_leitura\&artigo_id=20365\&revista_caderno=25. Acesso em: 7 maio 2019. 
RELAÇÃO trabalhista: entenda os direitos da mulher! 2017. Disponível em: https://www.metadados.com.br/blog/relacao-trabalhista-entenda-os-direitos-da-mulher/. Acesso em: 7 jun. 2019.

RIBEIRO, Djamila. Quem tem medo do feminismo negro? São Paulo: Companhia de Letras, 2018.

O que é lugar de fala? Belo Horizonte: Letramento: Justificando, 2017.

Feminismo negro para um novo marco civilizatório. Revista Internacional de

Direitos Humanos, dez. 2016. Disponível em: https://sur.conectas.org/feminismo-negropara-um-novo-marco-civilizatorio/. Acesso em:15 maio 2019.

RIOS, Roger Raupp. Direito da antidiscriminação: discriminação direta, indireta e ações afirmativas. Porto Alegre: Livraria do advogado Editora, 2008.

SANTANA, Bianca. Gênero, raça e classe: categorias de análise para compreender (não só) as mulheres negras. 2016. Disponível em: https://www.ceert.org.br/noticias/generomulher/11378/genero-raca-e-classe-categorias-de-analise-para-compreender-nao-so-asmulheres-negras. Acesso em: 29 set. 2018.

SANTOS, Sales Augusto; MORENO, João Vitor; BERTÚLIO, Dora Lúcia. O processo de aprovação do Estatuto da Igualdade Racial Lei n. 12.288, de 20 de julho de 2010. Brasília: INESC, 2011.

SANTOS, Walkyria Chagas da Silva. A mulher negra brasileira. Revista África e Africanidades, ano 2, n. 5, maio 2009. Disponível em: http://www.africaeafricanidades.com.br/documentos/A_mulher_negra_brasileira.pdf. Acesso em: 22 maio 2019.

SILVA, José Afonso. Curso de direito constitucional positivo. 37. ed., ver. e atual. até a Emenda Constitucional n. 76, de 28.11.2013. São Paulo: Malheiros Editores, 2014.

SIMÃO, Calil (coord.). Estatuto da igualdade racial: comentários doutrinários. Leme, SP: J. H. Mizuno, 2011. 
SUPTITZ, Bruna. Para Karen Pinheiro. Entrevistada: Karen Luise Vilanova Batista de Souza Pinheiro. Jornal do Comércio, 19 nov. 2018. http://www.ajuris.org.br/sitenovo/wpcontent/uploads/2018/11/19-11-2018-Entrevista-JC-Dra-Karen-Luise-Pinheiro.pdf. Acesso em: 14 maio 2019.

THEMIS - Gênero, Justiça e Direitos Humanos. História. [2019?]. Disponível em: http://themis.org.br/somos/historia/. Acesso em: 14 maio 2019.

TIBURI, Marcia. Feminismo em comum. 4. ed. Rio de Janeiro: Rosa dos Tempos, 2018.

VILARDAGA, Vicente; CAVICCHIOLI, Giorgia. Continuamos escravos. IstoÉ, 11 maio 2018. Disponível em: https://istoe.com.br/continuamos-escravos/4/. Acesso em: 20 abril. 2019.

WERNECK, Jurema Werneck; IRACI, Nilza. A situação dos direitos humanos das mulheres negras no Brasil: violências e violações. 2017. Disponível em: http://fopir.org.br/wp-content/uploads/2017/01/Dossie-Mulheres-Negras-.pdf. Acesso em: 27 set. 2018 . 